\title{
Effect of diet energy density and genomic residual feed intake on prebred dairy heifer feed efficiency, growth, and manure excretion*
}

\author{
K. T. Williams, ${ }^{1}$ K. A. Weigel, ${ }^{1}$ W. K. Coblentz, ${ }^{2}$ N. M. Esser, ${ }^{3}$ H. Schlesser, ${ }^{4}$ P. C. Hoffman,,${ }^{1,5}$ H. Su, ${ }^{6}$ \\ and M. S. Akins ${ }^{1} \dagger$ \\ ${ }^{1}$ Department of Dairy Science, University of Wisconsin-Madison, Madison 53706 \\ ${ }^{2}$ USDA Dairy Forage Research Center, Marshfield, WI 54449 \\ ${ }^{3}$ Marshfield Agricultural Research Station, University of Wisconsin, Marshfield 54449 \\ ${ }^{4}$ Marathon County Extension, University of Wisconsin-Extension, Wausau 54403 \\ ${ }^{5}$ Vita Plus Corporation, Madison, WI 53713 \\ ${ }^{6}$ Department of Animal Nutrition and Feed Science, China Agricultural University, Beijing, China 100083
}

\section{ABSTRACT}

The objective of this study was to determine the growth, feed efficiency, and manure excretion of prebred dairy heifers with differing predicted genomic residual feed intakes (RFI) when offered diets differing in energy density. Prebred Holstein heifers $(\mathrm{n}=128$, ages 4 to $8 \mathrm{mo}$ ) were blocked by weight (low, mediumlow, medium-high, or high) with 32 heifers per block. Heifers in each weight block were grouped by RFI and randomly assigned to obtain 2 pens of high (HRFI) and 2 pens of low RFI (LRFI) heifers within each block (8 heifers/pen). Heifers with LRFI were hypothesized to have greater feed efficiency than HRFI heifers. Dietary treatments were a high-energy diet (HE; 66.6\% total digestible nutrients, $14.0 \%$ crude protein, and $36.3 \%$ neutral detergent fiber, dry matter basis) and a low-energy diet (LE; $63.8 \%$ total digestible nutrients, $13.5 \%$ crude protein, and $41.2 \%$ neutral detergent fiber, dry matter basis). Each pen of heifers was randomly assigned to a treatment to obtain a $2 \times 2$ factorial arrangement $(2$ RFI levels $\times 2$ diet energy densities). Diets were offered in a 120-d trial. Dry matter intake was not affected by diet, RFI, or their interaction. Average daily gain (ADG) was affected by diet, with heifers fed HE having greater ADG than heifers fed LE. In addition, RFI affected ADG, with LRFI heifers having greater ADG than HRFI heifers, whereas the interaction of RFI and diet was not significant. Feed efficiency was improved for heifers fed the HE diet, but it was not affected by RFI or the interaction of RFI and diet. Overall, feed efficiency of prebred heifers was not dependent on

Received August 6, 2018.

Accepted January 14, 2019.

†Corresponding author: msakins@wisc.edu predicted genomic RFI, because the greater ADG of LRFI heifers was accompanied by slightly higher dry matter intake. Feed efficiency of heifers was reduced when heifers were fed the LE diet, but this resulted in more optimal ADG compared with the HE diet fed for ad libitum intake.

Key words: dairy heifer, diet energy, residual feed intake

\section{INTRODUCTION}

The primary goals in a replacement heifer-rearing program are to control rearing costs, achieve an optimal growth rate, and have heifers calve by 22 to 24 mo of age while avoiding compromising prepubertal mammary gland development and creation of any unnecessary environmental burdens. Prepubertal heifer nutrition is critical, because significant nutritional factors can affect production as a lactating cow. It is necessary for prepubertal heifers to gain adequate weight so heifers are large enough (55\% of mature weight) and have gone through puberty before first breeding by 13 mo of age. Excessive gains can lead to high body condition, with the suggested ADG ranging from 0.8 to $1.0 \mathrm{~kg} / \mathrm{d}$ (Hoffman, 1997). A meta-analysis by Zanton and Heinrichs (2005) concluded that ADG for heifers in the prepubertal stage should be approximately $0.8 \mathrm{~kg} / \mathrm{d}$ to maximize first-lactation milk production. Growth potential for heifers was greater than these suggested guidelines, as a previous study feeding a high-concentrate diet (1.87 Mcal of $\mathrm{NE}_{\mathrm{M}} / \mathrm{kg}$ of $\mathrm{DM}$ and $18.3 \% \mathrm{CP}$ ) to prepubertal heifers for $12 \mathrm{wk}$ found gains of 1.1 to $1.2 \mathrm{~kg} / \mathrm{d}$ with greater rib and perirenal fat deposition (Davis Rincker et al., 2008). Radcliff et al. (1997) also demonstrated heifer growth potential of 1.2 to $1.3 \mathrm{~kg} / \mathrm{d}$ when feeding a high-energy and high-protein diet (1.83 Mcal of $\mathrm{NE}_{\mathrm{M}} /$ $\mathrm{kg}$ of DM and $19.4 \% \mathrm{CP}$ ), resulting in increased carcass fat content and BCS with no difference in height or 
pelvic area at puberty. However, in their study, days to puberty were reduced by approximately $50 \mathrm{~d}$, which suggested a potential advantage of decreasing production costs due to fewer days on feed before first parturition, provided no other negative effects on lactation performance were found.

To achieve a balance between nutrition costs, growth, and production, Koch et al. (1963) proposed residual feed intake (RFI) as a tool for selecting animals with greater feed efficiency. Residual feed intake is defined as the difference between an animal's actual energy intake and its expected energy intake, where the latter is based on the animal's maintenance requirements and production level and is phenotypically independent of production and body size (Koch et al., 1963). Genomic selection for improved efficiency of consumed dietary energy in lactating cows has become a key priority in dairy cattle improvement programs worldwide (Berry et al., 2014; de Haas et al., 2015; Pryce et al., 2015). However, relatively few studies have considered selection for feed efficiency in growing heifers (Pryce et al., 2012), or the potential for a correlated response in feed efficiency among growing heifers due to selection for their improved efficiency in lactating cows. Williams et al. (2011) observed that the $10 \%$ most-efficient heifers (250 d of age) ate $1.7 \mathrm{~kg}$ of $\mathrm{DM} / \mathrm{d}$ less for a similar rate of gain than the $10 \%$ least-efficient heifers when fed alfalfa cubes. Animals are considered as more efficient (negative RFI) if they consume less feed than expected, compared with their cohorts, without any negative effects on growth and production. Animals are considered as less efficient (positive RFI) if they consume more feed than other animals in the same cohort after accounting for differences in growth or production. Benefits of improving feed efficiency include (1) potential improvements in growth rates, (2) reduced feed costs as a result of less DMI per unit gain, and (3) lower manure excretions, thereby contributing directly to dairy farm profitability.

To date, no studies have investigated the interaction between genomic RFI and dietary energy content in prepubertal Holstein dairy heifers. The objective of our study was to determine the growth, feed efficiency, and manure excretion of prebred dairy heifers differing in RFI when offered diets formulated at high and low energy densities. We hypothesized that the heifers with lower genomic RFI would have better feed efficiency. In addition, we hypothesized that heifers would have better feed efficiency when fed a higher-energy diet. An interaction of genomic RFI and diet energy content was also hypothesized to occur, with low-genomic RFI heifers having a greater response in feed efficiency than the high-genomic RFI heifers when fed the high-energy diet.

\section{MATERIALS AND METHODS}

\section{Animals, Housing, and Diets}

All animal handling procedures for this experiment were approved by the Research Animal Resources Committee of the University of Wisconsin-Madison (protocol \#A005117). One hundred twenty-eight prebred (ages 4-8 mo) Holstein heifers were stratified into 4 blocks (32 heifers/block) based on initial BW (low = $169 \pm 4.7 \mathrm{~kg}$; medium-low $=205 \pm 6.2 \mathrm{~kg}$; mediumhigh $=241 \pm 2.2 \mathrm{~kg}$; high $=286 \pm 3.7 \mathrm{~kg}$ ) in a $120-\mathrm{d}$ feeding study. Within each weight block there were 4 identical research pens, each containing 8 heifers; therefore, a total of 16 pens, each populated with 8 heifers, were included in the study. Within each weight block, heifers were further segregated into low RFI (LRFI; $\mathrm{n}=16$ /block) and high RFI heifers (HRFI; $\mathrm{n}=16$ / block), which were predicted to be more and less efficient, respectively. The LRFI heifer pens had a mean genomic RFI difference of $-0.069 \pm 0.096 \mathrm{~kg}$ of DM from predicted intake, with the mean pen minimum and maximum being -0.26 and 0.027 . The HRFI heifer pens had a mean genomic RFI difference of $0.13 \pm$ $0.073 \mathrm{~kg}$ of DM from predicted intake, with the mean pen minimum and maximum being 0.051 and 0.27 . Overall individual-animal mean genomic RFI difference across all animals in the study was $0.031 \pm 0.13 \mathrm{~kg}$ of DM from predicted intakes, with a range of -0.38 to 0.38. High- (HE) and low-energy ( LE) diets comprised the other aspect of the treatment structure, with each RFI treatment pen randomized to either $\mathrm{HE}$ or LE diets, resulting in a 2 (RFI levels) $\times 2$ (dietary energy densities) factorial arrangement of treatments, in which pen served as the experimental unit (St-Pierre, 2007).

Animals were housed at the University of Wisconsin Marshfield Agricultural Research Station (Marshfield, $\mathrm{WI}$ ). Heifers were housed in $4.5-\times 9.0-\mathrm{m}$ pens within a 2 -row, bedded pack barn that contained a feeding alley, a $30-\mathrm{m}^{2}$ group resting area that was refreshed with new sawdust bedding added 5 times/week, $0.56 \mathrm{~m}$ of bunk space per heifer at a neck-rail bunk line, and continuous access to fresh water. Diets were delivered as TMR between 0900 and $1100 \mathrm{~h}$ each day, and feed was pushed up at least twice daily.

Ingredient and nutrient composition of the treatment diets and individual dietary components are presented in Table 1. Heifers were offered 1 of 2 diets: (1) HE, composed of $52 \%$ alfalfa silage, $15.6 \%$ corn silage, $28.7 \%$ dry corn, and $3.7 \%$ soybean meal; or (2) LE, composed of $55 \%$ alfalfa silage, $31.6 \%$ corn silage, $9.7 \%$ dry corn, and $3.6 \%$ soybean meal. Diets were formulated to provide $63 \%$ TDN for LE and $66 \%$ TDN for $\mathrm{HE}$, with similar protein contents (13.5 to $14 \% \mathrm{CP}$ ) 
to determine effects of additional energy supply. These formulations resulted in a reduction of $\mathrm{ME}$ for the $\mathrm{LE}$ (2.48 Mcal of $\mathrm{ME} / \mathrm{kg}$ of $\mathrm{DM})$ diet relative to the $\mathrm{HE}$ diet (2.60 Mcal of ME $/ \mathrm{kg}$ of $\mathrm{DM})$. Diets were formulated for daily gains of 0.90 to $1.0 \mathrm{~kg} / \mathrm{d}$ for heifers fed LE and 1.1 to $1.2 \mathrm{~kg} / \mathrm{d}$ for heifers fed HE. Daily gain goals for LE were for optimal gains, whereas HE were for above the optimal range. The optimal daily gain was based on age, weight, mature weight of lactating cows in the research herd, and goal of first breeding by 13 mo of age to attain a goal of first calving between 22 and 24 mo. Parameters for diet formulation using NRC (2001) equations were mean age of 8.5 mo during the study, average BW of $280 \mathrm{~kg}$ for LE and $300 \mathrm{~kg}$ for HE, BCS of 3.0, mature weight of $750 \mathrm{~kg}$ based on herd measurements, and first calving age of 22 mo (assuming a first insemination at 13 mo of age). The study was conducted from July through October 2015 (midsummer to midautumn) with no cold stress adjustments made in the model, as the daily average temperature was not below $4^{\circ} \mathrm{C}$ and few nights were below freezing. Average temperature during the study was $22^{\circ} \mathrm{C}$, with heifers not showing signs of heat stress (panting) during the study, the daily average temperature not above $26^{\circ} \mathrm{C}$, and few days with high temperatures above $30^{\circ} \mathrm{C}$. Requirements for LE heifer to gain $0.95 \mathrm{~kg} / \mathrm{d}$ were 15.1 Mcal of ME and $554 \mathrm{~g}$ of MP, and the requirement for HE heifers to gain $1.15 \mathrm{~kg} / \mathrm{d}$ were $16.6 \mathrm{Mcal}$ of ME and $633 \mathrm{~g}$ of MP (NRC, 2001). Using NRC (2001) estimated intakes $(6.75 \mathrm{~kg}$ of DM for $\mathrm{LE}$ and $7.08 \mathrm{~kg}$ of DM for $\mathrm{HE}$ ) and actual forage composition data during the study, the LE diet was estimated to result in $0.98 \mathrm{~kg}$ of gain based on MP supply and $1.16 \mathrm{~kg}$ of gain based on ME supply; the HE diet was estimated to result in $1.11 \mathrm{~kg}$ of gain based on MP supply and $1.28 \mathrm{~kg}$ of gain based on ME supply. Diets were offered as a TMR for ad libitum intake during the $120-\mathrm{d}$ treatment period. The TMR amounts were adjusted daily to maintain a bunk score of $1(2-3 \%$ refusals $)$, where $0=$ no feed particles remaining; $1=$ only scattered feed particles remaining; $2=$ numerous particles remaining, but concrete floor is still easily visible; or $3=$ feed particles completely covering the concrete bunk floor (Hoffman et al., 2008). Orts were collected daily at $0830 \mathrm{~h}$, weighed in a tared, plastic storage bin, subsampled, and frozen $\left(-20^{\circ} \mathrm{C}\right)$ for future analysis. Diets (TMR) were sampled daily at feed delivery and frozen $\left(-20^{\circ} \mathrm{C}\right)$ for future analysis. Individual feed components were collected once weekly and frozen $\left(-20^{\circ} \mathrm{C}\right)$ for future analysis.

\section{Genomic RFI}

Genomic predictions for RFI as a lactating cow were computed for the heifers in this study using $60,671 \mathrm{SNP}$ markers throughout the genome with genomic BLUP. The reference population consisted of 3,522 Holstein cows at 10 research stations throughout the United States and Canada; these cows had individual DMI, milk yield, milk composition, BW, and BCS data recorded daily over a minimum of $28 \mathrm{~d}$ during the period from 50 to $200 \mathrm{~d}$ postpartum (Tempelman et al., 2015). Phenotypes for RFI were calculated as the difference between consumed DMI $(\mathrm{kg} / \mathrm{d})$ and expected DMI, where the expectation for a given cow is based on her secreted milk energy, metabolic BW, and BW change relative to other cows in her experimental cohort. Cows in the reference population had data regarding SNP genotypes and RFI phenotypes, whereas heifers in the current study had SNP genotypes only, with RFI phenotypes treated as missing while predicting their genomic breeding values for RFI based on their genomic similarity to cows in the reference population. It should be noted that the genomic prediction for RFI of a lactating cow reflects the expected increase or decrease in DMI relative to contemporary cows with similar milk yield, milk composition, body size, and body composition. This trait is different from RFI of a growing heifer, which would reflect the increase or decrease in DMI relative to contemporary heifers with similar growth rate and body size.

\section{BW, Frame, and Ultrasound Measurements}

Initial and final BW were taken before feeding for 3 consecutive days ( $\mathrm{d}-2,-1$, and 0 for initial, and $\mathrm{d}$ 118, 119, and 120 for final) using a cattle chute (Real Tuff, Clearbrook, MN) and electronic scale (Tru-Test Inc., Mineral Wells, TX). Body measurements were assessed on 1 of the 3 weigh days at the beginning and end of the trial and included heart girth, body length, hip height, hip width, wither height, and BCS. Body condition score was taken by 2 trained evaluators on a scale of 1 to 5 , where $1=$ emaciated and $5=$ obese (Wildman et al., 1982); 0.5-unit increments were used whenever appropriate to better describe each heifer's body condition.

Ultrasound measurements (Aloka Echo Camera model SSD-500 and Aloka Ultrasound Probe UST5044-3.5, Aloka Co. Ltd., Japan) of rump fat thickness and kidney fat depth were taken on 1 of the $3 \mathrm{~d}$ during each measurement time. Animals were brushed clean of debris and vegetable oil was applied to the ultrasound sites as an imaging medium. Ultrasound measures of rump fat and kidney fat were used to assess external and internal body fat, respectively, as a confirmation of BCS (Schröder and Staufenbiel, 2006; Ribeiro et al., 2008). The examination site for rump fat was located in the sacral region between the caudal one-quarter and 
one-fifth connection line, going from the dorsal part of the pins to the hooks (Schröder and Staufenbiel, 2006). Rump fat is positioned between the skin and the profound fascia, which is directly on the gluteal muscle and appears as a white line. The point of measurement is underneath the layer of skin and extends to the profound fascia. The examination site for kidney fat is located between the first lumbar and the 13th rib (Ribeiro et al., 2008). The point of measurement is taken from the bottom of the spine or rib to the bottom of the fat deposit.

\section{Whole-Pen Manure Collection}

Whole-pen manure collections were conducted during wk 8 and 16 to quantify DM, OM, NDF, and N excretion within each pen during a 48-h collection period (Coblentz et al., 2013). Due to structural barn limitations, heifers were moved to clean collection pens bedded with preweighed wood shavings for the collection period. Separation boards were placed between pens during the collection period to prevent crosscontamination of urine and manure between collection pens (Hoffman et al., 2007). Manure was allowed to accumulate in pens for $48 \mathrm{~h}$.

After $48 \mathrm{~h}$, heifers were removed from pens and manure was collected using a skid-loader and hand shovels to ensure removal from all areas of the pen. All components (wood shavings, urine, and feces) were placed in a small $4.4-\mathrm{m}^{3}$ manure spreader (H\&S Manufacturing Company Inc., Marshfield, WI) fitted with electronic load cells (Digi-star, Fort Atkinson, WI). Spreader contents were weighed immediately, thereby ensuring accuracy by eliminating leakage from the spreader during transport. Subsequently, all contents were unloaded onto a clean, flat concrete slab, sampled from 10 to

Table 1. Ingredient and nutrient composition of treatment diets and ingredients

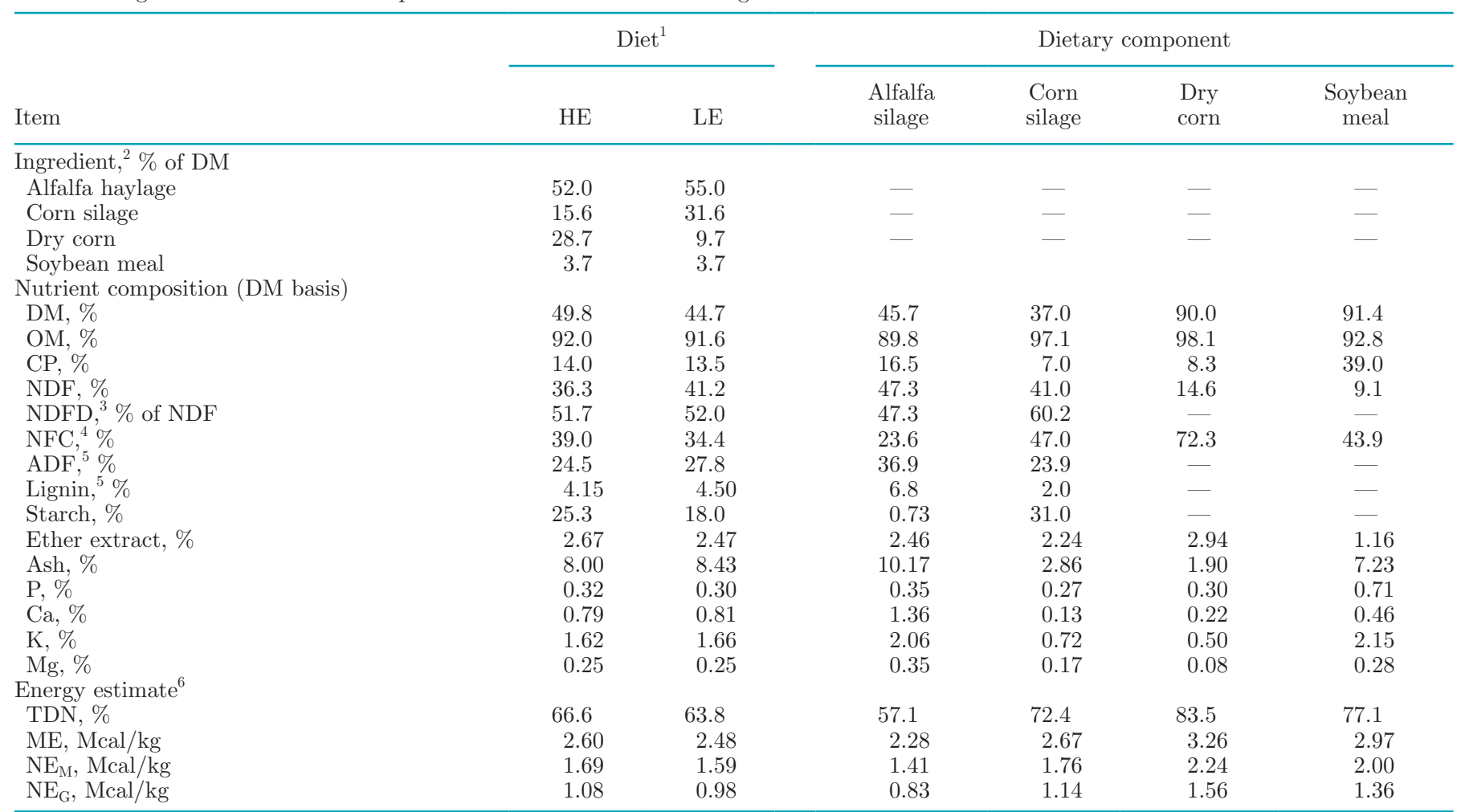

${ }^{1} \mathrm{HE}($ high energy) $=$ alfalfa silage, corn silage, soybean meal, and $29 \%$ dry corn to increase energy offered at ad libitum intake; LE (low energy) $=$ alfalfa silage, corn silage, soybean meal, and $10 \%$ dry corn to lower energy offered at ad libitum intake.

${ }^{2}$ Mineral package contained $70.0 \%$ calcium carbonate, $15.1 \%$ salt, $5.04 \%$ magnesium oxide, $2.12 \%$ sulfur, $1.61 \% 1,600 \mathrm{mg} / \mathrm{kg}$ of Se, $1.56 \%$ vitamin A, $0.91 \%$ manganese sulfate $32 \%, 0.68 \%$ vitamin E $50 \%, 0.65 \%$ copper sulfate, $0.50 \%$ vitamin $\mathrm{D}, 0.50 \%$ mineral oil, $0.33 \%$ iodine mix $7.3 \%$, $0.23 \%$ thiamin mononitrate $99 \%, 0.025 \%$ cobalt carbonate $46 \%$, and $0.76 \%$ Rumensin (Elanco Animal Health, Greenfield, IN) 90.7 premix. Mineral package was blended into the total diet at a rate of $113 \mathrm{~g} /$ heifer per day and delivered as a TMR.

${ }^{3} \mathrm{NDF}$ digestibility determined following a 48-h digestion in buffered rumen fluid.

${ }^{4} \mathrm{NFC}=100-(\% \mathrm{NDF}+\% \mathrm{CP}+\%$ ether extract $+\%$ ash $)$.

${ }^{5}$ Concentrations of ADF and lignin were determined for wk 4, 8, 12, and 16 .

${ }^{6}$ Calculated according to NRC (2001). 
15 locations at various depths in the pile, and placed into 19-L plastic buckets. Samples were then mixed thoroughly, and a subsample placed in a 3.8-L plastic storage bag and stored in a cooler over ice, pending transport to the laboratory for analysis.

Manure samples were thoroughly mixed, and a $20-\mathrm{g}$ subsample from each pen was placed in an aluminum pan and dried for $24 \mathrm{~h}$ at $100^{\circ} \mathrm{C}$ to determine DM concentrations. Samples were analyzed in quadruplicate, and DM concentrations were averaged to determine the mean DM concentration for each pen manure sample. After DM analysis, samples were combusted at $500^{\circ} \mathrm{C}$ for $6 \mathrm{~h}$ in a muffle furnace to determine ash concentration. Fresh bedding samples, taken from pens immediately following distribution and before placing animals in the pen, were collected from the pens, composited, and analyzed using similar methods as manure samples.

\section{Laboratory Analysis of Treatment Diets}

Individual feed components, orts, and TMR samples were thawed weekly, before compositing. The TMR and ort samples were composited and subsampled to obtain a 400- to 500-g sample. Samples were then dried to constant weight under forced air at $55^{\circ} \mathrm{C}$, ground through a $1-\mathrm{mm}$ screen in a Thomas model 4 Wiley mill (Thomas Scientific, Swedesboro, NJ), and stored in plastic sample bags. All TMR samples were analyzed by the University of Wisconsin Soil and Forage Analysis Laboratory (Marshfield, WI) for (1) DM (AOAC, 1990); (2) CP by a macro-Kjeldahl procedure (AOAC International, 1998; method 988.05); (3) ash by combustion in a muffle furnace at $\left(500^{\circ} \mathrm{C}\right)$ for $6 \mathrm{~h}$; (4) starch (YSI model 2700D, Yellow Springs Instrument Co., Yellow Springs, OH); (5) NDF by the methods of Goering and Van Soest (1970), with both heat-stable amylase and sodium sulfite included within the NDF solution; (6) 48-h in vitro digestion of NDF (NDFD) in buffered rumen fluid using procedures described in detail by Kruse et al. (2010); (7) ether extract (AOAC, 1990; method 920.29) using equal parts anhydrous ether and petroleum ether as solvents; (8) Ca, K, and $\mathrm{Mg}$ by atomic absorption spectroscopy; and (9) P by colorimetric methodology (Schulte et al., 1987). Rumen fluid for in vitro digestion analysis was obtained from 2 nonlactating Holstein cows offered an alfalfa haylage diet (16.7\% CP, 55.6\% TDN, 49.5\% NDF). Samples of TMR obtained from wk 4, 8, 12, and 16 were also analyzed for ADF and ADL by the methods of Goering and Van Soest (1970) without preliminary digestion in neutral detergent. Calculations of TDN, ME, $\mathrm{NE}_{\mathrm{G}}$, and $\mathrm{NE}_{\mathrm{M}}$ of treatment diets were made using summative equations (NRC, 2001), with 48-h NDFD serving as a digestibility coefficient for NDF to estimate truly digestible fiber.

\section{Calculation of Diet Digestibility}

Digestibilities of DM, OM, NDF, and apparent N of diets were determined on a whole-pen basis during wk 8 and 16 of the trial. Whole-pen manure samples, fresh bedding composites, and weekly pen composites of diets and orts were dried to constant weight under forced air at $55^{\circ} \mathrm{C}$, then ground through a $1-\mathrm{mm}$ screen in a Thomas model 4 Wiley mill (Thomas Scientific). Concentrations of ash in diet and ort samples were determined from 1.0-g subsamples by combustion in a muffle furnace at $500^{\circ} \mathrm{C}$ for $6 \mathrm{~h}, \mathrm{~N}$ was determined by a rapid combustion procedure (AOAC International, 1998; method 990.63; TruMac CN, Leco Corporation, Saint Joseph, MI), and NDF was determined using batch procedures that included heat-stable $\alpha$-amylase in the NDF solution (Ankom Technologies, Macedon, NY). Organic matter was calculated as 100 - ash\%. Nutrient intakes were calculated by difference of nutrient amounts fed and ort nutrient amounts. Nutrients excreted in manure were calculated by multiplying the manure DM excreted by the manure nutrient concentration. Nutrient digestibilities were calculated by as $100-($ manure nutrient amount/nutrient intake $\times 100)$ at each collection period.

\section{Statistics}

All data were analyzed using the PROC MIXED procedure of SAS (Version 9.4; SAS Institute Inc., 2012) as a randomized complete block design with 4 blocks and a $2 \times 2$ factorial arrangement of treatments $(2$ levels of RFI and 2 levels of diet energy), where the pen served as the experimental unit throughout. The model included RFI, diet, RFI $\times$ diet interaction, and block as fixed effects. Heifers were blocked deliberately on the basis of weight; therefore, block was considered a fixed variable rather than random. Least squares means were determined and treatment means compared when a significant interaction or significant main treatment effects were found. Statistical significance and trends were declared at $P \leq 0.05$ and $0.05<P \leq 0.10$, respectively.

\section{RESULTS AND DISCUSSION}

\section{Diet Formulation}

Ingredient and nutrient composition of treatment diets and individual dietary components are presented 
in Table 1. Weekly analysis indicated that experimental diets were isonitrogenous. Energy was decreased due to greater inclusion of corn silage, which increased NDF by 4.9 percentage units for the LE diet $(41.2 \%)$ compared with the HE diet $(36.3 \%)$. The purpose of increasing the NDF concentration in the diet was to decrease DMI, as defined by the gut fill theory (Mertens, 1973). Digestibility of NDF remained similar for both diets, at $52 \%$ NDFD, expressed on a percent of NDF basis. Concentrations of TDN and ME for the HE diet (66.6\% TDN and 2.60 Mcal of ME/ $\mathrm{kg}$ of DM) were decreased with the addition of corn silage and reduction of dry corn in the LE diet (63.8\% TDN and $2.48 \mathrm{Mcal}$ of ME/ $\mathrm{kg}$ of DM). According to Hoffman et al. (2008), the energy concentration of the HE diet was excessive for heifers of this BW at ad libitum intakes. A high-energy diet, such as HE, can cause rapid growth of prepubertal dairy heifers and overconditioning. Characteristics of the LE diet were more optimal for heifers of this age and size.

\section{Nutrient Intakes}

Dry matter intake (Table 2 ) was not affected by RFI $(P=0.17)$, diet energy $(P=0.14)$, or their interaction $(P=0.66)$. Contrary to our hypothesis, heifers fed the LE diet consumed numerically more DM than heifers fed HE. In previous dietary dilution studies (Greter et al., 2008; Coblentz et al., 2015), diets were diluted with forages such as eastern gamagrass and straw to increase NDF but decrease energy density and DMI. In the current study, energy was reduced via the addition of corn silage in place of corn grain. Corn silage is a preferred feedstuff and likely had less of an effect on intake than if a moderate- or low-quality forage was used to reduce the energy concentration. Changing the forage source for energy dilution with longer particle length or higher NDF may have altered our results. Heifers with different genomic RFI did not exhibit $(P$ $=0.17$ ) different DMI (7.8 and $7.4 \mathrm{~kg}$ of DMI for LRFI and HRFI, respectively), but previous work by Williams et al. (2011) showed that the 10\% most-efficient heifers (low RFI) consumed $1.7 \mathrm{~kg} / \mathrm{d}$ less DMI than the $10 \%$ least-efficient heifers at the same rate of growth. As expected, NDF intake was greater $(P=0.01)$ for heifers offered the LE diet due to higher diet NDF content and DMI. As a percent of BW, NDF intake was greater $(P=0.01)$ for heifers fed the LE diet $(1.14 \%$ of BW as NDF) compared with the HE diet (0.91\% of BW as NDF), which varies from results of Hoffman et al. (2008), who stated heifers will typically consume $1 \%$ of BW as NDF. Heifers fed HE may have had lower $\mathrm{NDF}$ intakes as a percent of BW due to intake being controlled via energy intake rather than fill. Greter et al. (2008) concluded that, as diet NDF concentration increases by feeding a dilutant forage, DMI will then decrease due to fill effects. On the contrary, Quigley et al. (1986) reported that whenever NDF was less than $42 \%$, no correlation existed between DMI and diet NDF concentration. Our results agreed with Quigley et al. (1986), in that heifers fed a higher NDF diet (LE diet) had greater DMI $(7.83 \mathrm{~kg}$ of DM/d) than those fed a lower NDF diet (HE diet; $7.39 \mathrm{~kg}$ of DM/d), as both diets contained an NDF concentration of less than $42 \%$. Alternatively, DMI for HE heifers may have been lower because the heifers met their energy requirements with less feed when offered the HE diet. Intakes of energy (TDN, ME, $\mathrm{NE}_{\mathrm{M}}$, or $\mathrm{NE}_{\mathrm{G}}$ ) were not significantly different $(P>0.14)$ between diets, RFI treatments, or their interaction. The interaction of diet and RFI did not affect intakes; thus, predicted RFI does not appear to affect feed efficiency whether heifers are fed diets causing a fill or chemostatic effect on intake. Additional work evaluating diets with greater fiber or energy levels would be useful to further elucidate diet interactions with predicted RFI on feed efficiency. The HE diet contained a greater concentration of starch (25.3 vs. $18.0 \%)$, resulting in an increase in starch intake for heifers fed the HE diet $(P<0.01)$. Crude protein and fat intakes were not different across treatments $(P$ $\geq 0.17$ ), at 1.05 and $0.20 \mathrm{~kg} / \mathrm{d}$, respectively. Mineral intakes were not different between RFI groups $(P \geq$ 0.17 ), but $\mathrm{Ca}$ and $\mathrm{K}$ intakes tended $(P \leq 0.07)$ to be greater for LE due to numerically greater DMI coupled with some variability in mineral concentrations across diets due to differences in diet composition.

\section{Heifer Growth and Performance}

Heifer growth and performance data are presented in Table 3. Initial BW $(227.5 \mathrm{~kg})$ and measurements were similar across dietary treatments $(P \geq 0.68)$ and RFI groups $(P \geq 0.21)$. Initial kidney fat differed $(P=0.04)$ between HRFI and LRFI heifers (11.1 vs. $11.4 \mathrm{~cm})$, as well as between HE and LE diets (11.4 vs. $11.1 \mathrm{~cm} ; P=$ 0.04). We noted a difference in final BW based on RFI (357.5 vs. $346.5 \mathrm{~kg}$ for LRFI and HRFI, respectively; $P<0.01)$ and $\operatorname{diet}(341.5$ vs. $362.5 \mathrm{~kg}$ for LE and HE, respectively; $P<0.01$ ), as well as a trend for interaction of main effects $(P=0.06)$. Final kidney fat was greater $(P=0.04)$ and rump fat tended $(P=0.06)$ to be greater for heifers offered the HE diet, with gains of kidney $(P=0.10)$ and rump fat $(P=0.08)$ tending be higher for heifers offered HE. The main effects of RFI $(P<0.03)$ and $\operatorname{diet}(P<0.01)$ also were significant for BW change and ADG, but associated interactions were not $(P \geq 0.52)$. The LRFI heifers had greater ADG $(1.09 \mathrm{~kg} / \mathrm{d})$ than HRFI heifers $(1.02 \mathrm{~kg} / \mathrm{d})$, which was 
Table 2. Nutrient intakes for prebred Holstein dairy heifers with different residual feed intake (RFI) and fed diets with different energy densities ${ }^{1}$

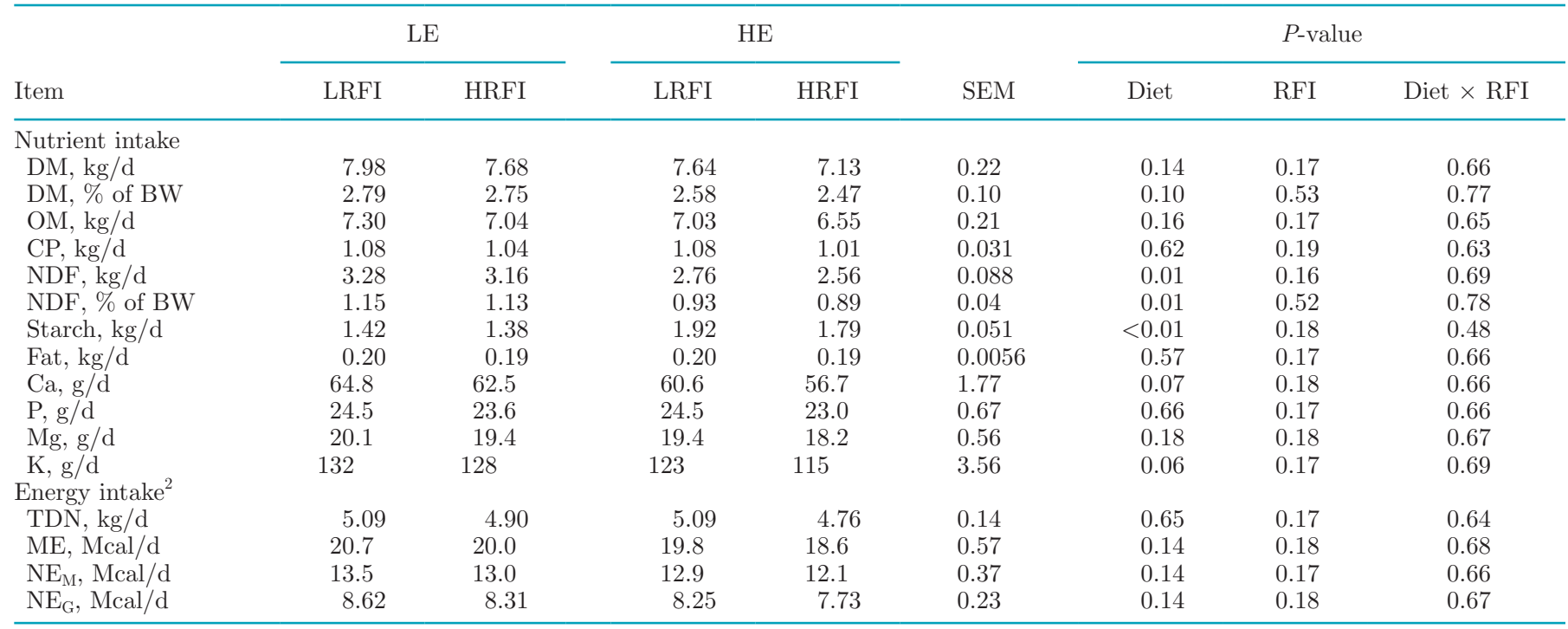

${ }^{1} \mathrm{HE}$ (high energy) = alfalfa silage, corn silage, soybean meal, and $29 \%$ dry corn to increase energy offered at ad libitum intake; LE (low energy) $=$ alfalfa silage, corn silage, soybean meal, and $10 \%$ dry corn to lower energy offered at ad libitum intake; LRFI = low-RFI heifer block; HRFI $=$ high-RFI heifer block.

${ }^{2}$ Energy calculations based on NRC (2001).

likely due to the numerically higher DMI and energy intakes. Heifers offered LE had a lower, but more optimal ADG $(0.97 \mathrm{~kg} / \mathrm{d})$ compared with those fed HE $(1.14$ $\mathrm{kg} / \mathrm{d}$ ). Daily gain of $1.14 \mathrm{~kg} / \mathrm{d}$ is excessive relative to targets for heifers of this age and BW (0.8 to $1.0 \mathrm{~kg} / \mathrm{d}$; Zanton and Heinrichs, 2005; Davis Rincker et al., 2008), indicating possible overconditioning and potentially decreased mammary growth for these heifers. In addition, heart girth gain was greater $(P<0.01)$ for the HE diet than the LE diet. Taken together, heifers fed the HE diet gained more internal and external adipose tissue, confirming additional body conditioning of these heifers compared with LE heifers. This confirms that both external and internal fat deposits will increase when a diet with excessive energy is offered. Feed efficiency was improved $(P<0.01)$ for heifers fed the HE diet (6.45 kg of DMI $/ \mathrm{kg}$ of gain), as compared with heifers fed the LE diet $(8.02 \mathrm{~kg}$ of DMI $/ \mathrm{kg}$ of gain). Similar results were found by Zanton and Heinrichs (2007) when limit-feeding heifers a high-forage ( $75 \%$ forage) or -concentrate $(75 \%$ concentrate) diet to achieve similar gains, with heifers fed the high-concentrate diet having improved feed efficiency. With the similar calculated energy intakes (Table 2) for the LE and HE diets, but greater $\mathrm{ADG}$ for $\mathrm{HE}$, the efficiency of conversion of $\mathrm{ME}$ to gain was greater for $\mathrm{HE}(16.8 \mathrm{Mcal}$ of $\mathrm{ME} / \mathrm{kg}$ of ADG) than for LE (20.9 Mcal of ME/ $\mathrm{kg}$ of ADG) and may be related to differences in the fermentation and digestion products from the LE and HE diets. In addition, the conversion of available $\mathrm{NE}_{\mathrm{G}}$ to shrunk weight gain after accounting for maintenance require- ments tended $(P=0.08)$ to be improved for heifers fed HE compared with LE (3.69 vs. 4.24 Mcal of $\mathrm{NE}_{\mathrm{G}} / \mathrm{kg}$ ).

Using the intake and feed composition results, the NRC (2001) model was used to re-evaluate estimated gains. Intakes of both $\mathrm{LE}$ and $\mathrm{HE}$ diets were greater than estimated by NRC $(6.77 \mathrm{~kg} / \mathrm{d}$ for $\mathrm{LE}$ and 7.01 $\mathrm{kg} / \mathrm{d}$ for $\mathrm{HE}$ ) using actual mean BW, which resulted in greater estimates of growth, especially for heifers offered LE. Heifers offered the LE diet had a mean DMI of $7.81 \mathrm{~kg} / \mathrm{d}$ and mean BW of $283 \mathrm{~kg}$ during the study, and based on these data the model estimates gains of $1.19 \mathrm{~kg} / \mathrm{d}$ based on MP supply and $1.49 \mathrm{~kg} / \mathrm{d}$ based on ME supply. Heifers fed the HE diet had a mean DMI of $7.36 \mathrm{~kg} / \mathrm{d}$ and mean BW of $296 \mathrm{~kg}$, with the model estimating gains of $1.17 \mathrm{~kg} / \mathrm{d}$ based on MP supply and 1.38 $\mathrm{kg} / \mathrm{d}$. Based on these predictions of gain, the actual gains were lower for heifers fed the LE diet, whereas the actual gains for $\mathrm{HE}$ were close to estimated gains based on MP supply. This may be due to differences in nutrient use efficiencies, fermentation products, or microbial protein synthesis for diets differing in fiber and starch content and subsequent availability of energy substrates and protein for growth.

Contrary to our hypothesis, feed efficiency was not affected $(P=0.48)$ by genomic RFI, with LRFI and HRFI heifers exhibiting 7.17 and $7.30 \mathrm{~kg}$ of DMI $/ \mathrm{kg}$ of gain, respectively. The genomic RFI predictions for lactating dairy cattle may not directly result in improved feed efficiency of prebred dairy heifers. The interaction of diet and RFI did not affect intakes; thus, predicted RFI does not appear to affect feed efficiency whether 
Table 3. Growth performance for prebred Holstein dairy heifers with different residual feed intakes (RFI) and fed diets with different energy densities over a 120 -d feeding period ${ }^{1}$

\begin{tabular}{|c|c|c|c|c|c|c|c|c|}
\hline \multirow[b]{2}{*}{ Item } & \multicolumn{2}{|c|}{$\mathrm{LE}$} & \multicolumn{2}{|c|}{$\mathrm{HE}$} & \multirow[b]{2}{*}{ SEM } & \multicolumn{3}{|c|}{$P$-value } \\
\hline & LRFI & HRFI & LRFI & HRFI & & Diet & RFI & Diet $\times$ RFI \\
\hline $\mathrm{BW}, \mathrm{kg}$ & 225 & 225 & 228 & 232 & 5.39 & 0.68 & 0.38 & 0.43 \\
\hline Body length, cm & 49.0 & 49.4 & 49.3 & 49.5 & 0.66 & 0.75 & 0.64 & 0.85 \\
\hline Heart girth, cm & 54.7 & 54.3 & 55.1 & 54.1 & 0.43 & 0.78 & 0.21 & 0.51 \\
\hline BCS & 2.71 & 2.73 & 2.77 & 2.62 & 0.05 & 0.67 & 0.32 & 0.22 \\
\hline \multicolumn{9}{|l|}{ Final } \\
\hline $\mathrm{BW}, \mathrm{kg}$ & 345 & 338 & 370 & 355 & 2.80 & $<0.01$ & $<0.01$ & 0.06 \\
\hline Body length, cm & 54.3 & 53.9 & 54.5 & 54.6 & 0.35 & 0.27 & 0.73 & 0.45 \\
\hline Hearth girth, cm & 63.7 & 63.8 & 65.6 & 64.5 & 0.20 & $<0.01$ & 0.09 & 0.05 \\
\hline BCS & 3.27 & 3.07 & 3.62 & 3.42 & 0.09 & 0.03 & 0.11 & 0.97 \\
\hline Rump fat, cm & 0.68 & 0.67 & 0.78 & 0.77 & 0.03 & 0.06 & 0.76 & 0.90 \\
\hline Kidney fat, cm & 13.3 & 12.9 & 14.0 & 13.7 & 0.50 & 0.04 & 0.22 & 0.69 \\
\hline BCS, units/120 d & 0.56 & 0.34 & 0.85 & 0.80 & 0.13 & 0.06 & 0.36 & 0.58 \\
\hline Rump fat, cm/120 d & 0.34 & 0.37 & 0.47 & 0.43 & 0.04 & 0.08 & 0.82 & 0.61 \\
\hline Kidney fat, $\mathrm{cm} / 120 \mathrm{~d}$ & 1.99 & 1.98 & 2.36 & 2.41 & 0.17 & 0.10 & 0.92 & 0.88 \\
\hline Feed efficiency, $\mathrm{kg}$ of feed $/ \mathrm{kg}$ of gain & 7.91 & 8.13 & 6.43 & 6.47 & 0.16 & $<0.01$ & 0.48 & 0.62 \\
\hline ME:gain, Mcal of ME $/ \mathrm{kg}$ of gain & 20.6 & 21.2 & 16.7 & 16.9 & 0.41 & $<0.01$ & 0.44 & 0.64 \\
\hline $\begin{array}{l}\mathrm{NE}_{\mathrm{G}} \text { : gain, Mcal of } \mathrm{NE}_{\mathrm{G}} \text { available } \\
\text { for gain } / \mathrm{kg} \text { of gain }{ }^{2}\end{array}$ & 4.23 & 4.24 & 3.76 & 3.62 & 0.22 & 0.08 & 0.81 & 0.72 \\
\hline
\end{tabular}

${ }^{1} \mathrm{HE}$ (high energy) = diet containing $52 \%$ alfalfa silage, corn silage, soybean meal, and $29 \%$ dry corn offered at ad libitum intake; LE (low energy) $=$ alfalfa silage, corn silage, soybean meal, and $10 \%$ dry corn to lower energy offered at ad libitum intake; LRFI = low-RFI heifer block; HRFI $=$ high-RFI heifer block.

${ }^{2}$ Efficiency to convert available $\mathrm{NE}_{\mathrm{G}}$ to gain after accounting for shrunk BW maintenance requirement according NRC (2001) equations.

heifers are fed diets that have a fill or chemostatic control of intake. Additional work evaluating diets with greater fiber or energy levels or limit fed would be useful to further elucidate diet interactions with predicted RFI on feed intake and efficiency. Our study design may have limited the observed difference, as the animals were either the $50 \%$ highest or lowest RFI in the blocks; thus, limited differences in genomic RFI would occur. Work by Macdonald et al. (2014) used the $10 \%$ lowest- or highest-RFI heifers from a previously measured population to determine if RFI as heifers would correlate to RFI as lactating cows. Those authors found a significant, but decreased, difference between the low- and high-RFI groups, with a 3\% improvement in feed efficiency for the low-RFI cows. However, Macdonald et al. (2014) found a 21\% improvement in feed efficiency as heifers; thus, the relationship of RFI as a heifer and lactating cow may not be always correlated and is not completely understood. It is well known that the accuracy of genomic predictions for young selection candidates depends critically on size of the reference population of older animals, with SNP genotypes and phenotypes for the trait of interest from which the genomic predictions are derived (Hayes et al., 2009).
In the present study, the reliability values (which represent the squared correlation between estimated and true genetic merit) for genomic predictions of RFI in the Holstein heifers were low, on the order of 25 to $30 \%$. The process of dividing heifers into low-RFI (more efficient) versus high-RFI (less efficient) categories was likely not precise enough in this case, and this imprecision could explain why RFI effects were not as large as one might expect if heifers had been categorized based on their true breeding values.

\section{Nutrient Digestibilities and Manure Excretions}

Nutrient intakes and digestibilities during wk 8 and 16 are presented in Table 4. Neither RFI nor the RFI $\times$ diet interaction significantly affected DMI or intake of $\mathrm{OM}, \mathrm{NDF}$, or $\mathrm{N}$ during wk 8 and $16(P \geq 0.17)$. We noted a trend $(P=0.07)$ for greater DMI for heifers offered the LE diet $(8.72 \mathrm{~kg} / \mathrm{d})$ compared with heifers offered HE $(8.02 \mathrm{~kg} / \mathrm{d})$. By design, heifers offered the LE diet consumed greater $(P<0.01) \mathrm{NDF}(3.84 \mathrm{~kg} / \mathrm{d})$ compared with heifers fed the HE diet $(3.09 \mathrm{~kg} / \mathrm{d})$. Nitrogen intakes remained consistent across all treatments (mean of $0.21 \mathrm{~kg} / \mathrm{d}$ ). Manure excretions of DM 
Table 4. Digestibilities of various nutrients for prebred Holstein dairy heifers with different genomic residual feed intake (RFI) and different diet energy densities ${ }^{1}$

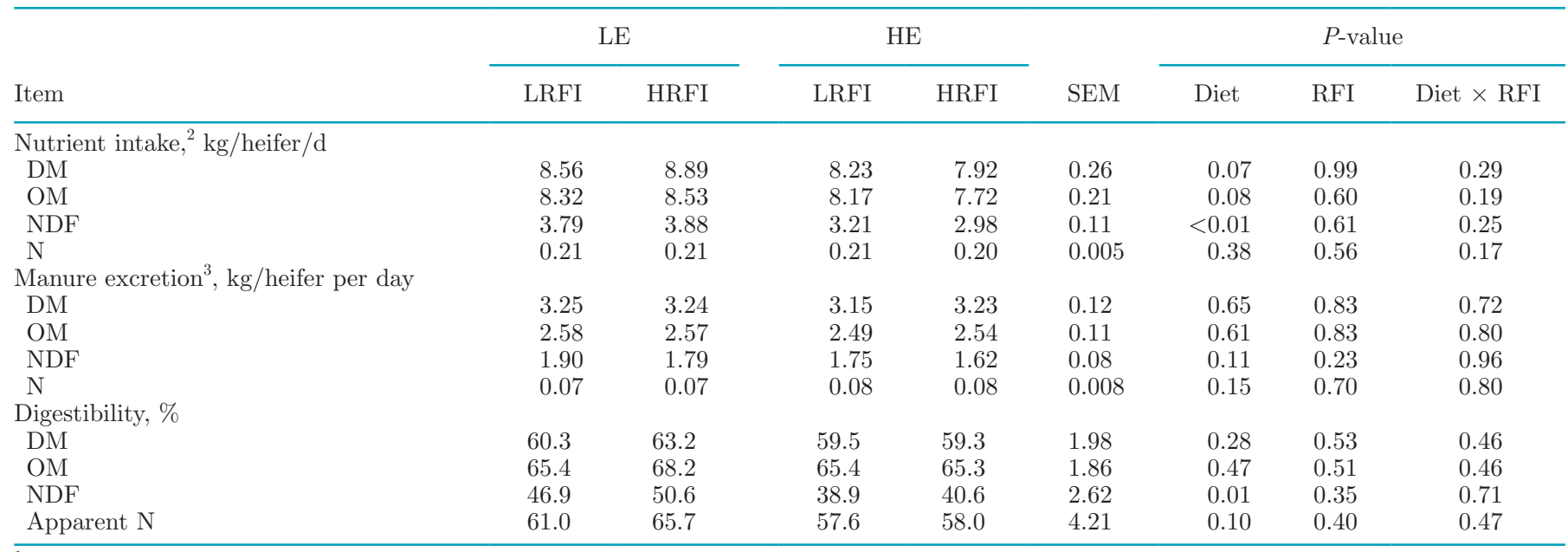

${ }^{1} \mathrm{HE}$ (high energy) = alfalfa silage, corn silage, soybean meal, and $29 \%$ dry corn to increase energy offered at ad libitum intake; LE (low energy) $=$ alfalfa silage, corn silage, soybean meal, and $10 \%$ dry corn to lower energy offered at ad libitum intake; LRFI = low-RFI heifer block; HRFI $=$ high-RFI heifer block.

${ }^{2}$ Based on wk 8 and 16 of trial only. All calculations were based on collective DMI and orts for the entire week of analysis, and then reported on a daily per heifer basis.

${ }^{3}$ Whole-pen manure excretion was collected on wk 8 and 16 after 48-h collection period.

did not differ based on RFI $(P=0.83)$, diet $(P=0.65)$, or the interaction of main effects $(P=0.72)$, nor did excretions of $\mathrm{OM}, \mathrm{NDF}$, or $\mathrm{N}(P \geq 0.11)$. Nutrient excretions of NDF were numerically lower for heifers fed the HE diet than for those fed the LE diet.

Digestibility of DM did not differ by RFI $(P=0.53)$, $\operatorname{diet}(P=0.28)$, or the RFI $\times$ diet interaction $(P=$ $0.46)$, nor did digestibilities of $\mathrm{OM}$ or $\mathrm{N}(P \geq 0.10)$. However, we found a tendency $(P=0.10)$ for lower apparent $\mathrm{N}$ digestibility for heifers fed the HE diet (57.8\%) than the LE diet (63.3\%). Digestibility of NDF was greater for LE $(P<0.01)$ than $\mathrm{HE}$, and was likely due to the NDFD being greater for corn silage $(60.2 \%$ NDFD) than for alfalfa silage ( $47.3 \%$ NDFD). The DM digestibility results were unexpected as the HE diet had greater starch and lower NDF, which we would expect to have greater DM digestibility. A potential explanation for the lack of difference between $\mathrm{HE}$ and LE for DM digestibility is the HE diet contained dry ground corn, which typically has a lower starch digestibility than starch from ensiled corn due to degradation of the kernel prolamins while in storage (Ferraretto et al., 2013). In addition, the NDF digestibility was greater for LE than HE; thus, the potential combined differences in starch digestibility and fiber digestibility may explain these results. Overall, it appears that reductions in manure excretions due to the dietary changes in our study (energy and feed sources) or selection for RFI were relatively small as compared with changes in ADG, feed efficiency, and adipose tissue.

\section{CONCLUSIONS}

Feed efficiency of prebred heifers was not dependent on genomic predictions for RFI under the conditions of this study. Dry matter intake was greater for heifers fed the LE diet, contrary to our hypothesis. Even with the greater DMI, this resulted in lower gains and decreased feed efficiency for heifers offered the LE diet compared with heifers fed the HE diet. Average daily gains for LRFI heifers were greater, likely due to a numerical increase in intake, but feed efficiency was not different from HRFI heifers. In this study, the effects of diet energy density were greater than those of genomic predisposition for RFI, likely due to the method for dividing heifers into high- or low-RFI groups. Feed efficiency was reduced when heifers were fed the LE diet, but this resulted in more optimal ADG than feeding a higher-energy diet ad libitum for extended periods. The LE diet was balanced using high inclusion of corn silage, which resulted in more optimal gains for prebred heifers. Future studies should focus on clarifying the genetic relationships between RFI as a growing heifer versus RFI as a lactating cow, as well as identifying other palatable, low-cost feeds for meeting the desired energy density of heifer rations.

\section{ACKNOWLEDGMENTS}

We acknowledge partial funding support from the USDA-Agricultural Research Service through a Spe- 
cific Cooperative Agreement (\#58-3655-4-052) and the SciMed Graduate Research Scholars program for graduate student funding.

\section{REFERENCES}

AOAC. 1990. Official Methods of Analysis. 15th ed. Assoc. Off. Anal. Chem., Arlington, VA.

AOAC International. 1998. Official Methods of Analysis. 16th ed. AOAC International, Arlington, VA.

Berry, D. P., M. P. Coffey, J. E. Pryce, Y. de Haas, P. Lovendahl, N. Krattenmacher, J. J. Crowley, Z. Wang, D. Spurlock, K. Weigel, K. Macdonald, and R. F. Veerkamp. 2014. International genetic evaluations for feed intake in dairy cattle through the collation of data from multiple sources. J. Dairy Sci. 97:3894-3905.

Coblentz, W. K., N. M. Esser, P. C. Hoffman, and M. S. Akins. 2015 Growth performance and sorting characteristics of corn silagealfalfa haylage diets with or without forage dilution offered to replacement Holstein dairy heifers. J. Dairy Sci. 98:8018-8034.

Coblentz, W. K., P. C. Hoffman, N. M. Esser, and M. G. Bertram. 2013. Technical note: Whole-pen assessments of nutrient excretion and digestibility from dairy replacement heifers housed in sandbedded freestalls. J. Anim. Sci. 91:4841-4848.

Davis Rincker, L. E., M. S. Weber Nielsen, L. T. Chapin, J. S. Liesman, and M. J. VandeHaar. 2008. Effects of feeding prepubertal heifers a high-energy diet for three, six, or twelve weeks on feed intake, body growth, and fat deposition. J. Dairy Sci. 91:1913-1925.

de Haas, Y., J. E. Pryce, M. P. L. Calus, E. Wall, D. P. Berry, P. Lovendahl, N. Krattenmacher, F. Miglior, K. Weigel, D. Spurlock, K. A. Macdonald, B. Hulsegge, and R. F. Veerkamp. 2015. Genomic prediction of dry matter intake in dairy cattle from an international data set consisting of research herds in Europe, North American, and Australasia. J. Dairy Sci. 98:6522-6534.

Ferraretto, L. F., P. M. Crump, and R. D. Shaver. 2013. Effect of cereal grain type and corn grain harvesting and processing methods on intake, digestion, and milk production by dairy cows through a meta-analysis. J. Dairy Sci. 96:533-550.

Goering, H. K., and P. J. Van Soest. 1970. Forage Fiber Analyses (Apparatus, Reagents, Procedures, and Some Applications). Agric. Handbook No. 379. USDA-ARS, Washington, DC.

Greter, A.M., T. J. DeVries, and M. A. von Keyserlingk. 2008. Nutrient intake and feeding behavior of growing dairy heifers: Effects of dietary dilution. J. Dairy Sci. 91:2786-2795.

Hayes, B. J., P. J. Bowman, A. J. Chamberlain, and M. E. Goddard. 2009. Invited review: Genomic selection in dairy cattle: Progress and challenges. J. Dairy Sci. 92:433-443.

Hoffman, P. C. 1997. Optimum body size of Holstein replacement heifers. J. Anim. Sci. 75:836-845.

Hoffman, P. C., C. R. Simson, and M. Wattiaux. 2007. Limit feeding of gravid Holstein heifers: Effect on growth, manure nutrient excretion, and subsequent early lactation performance. J. Dairy Sci. 90:946-954.

Hoffman, P. C., K. A. Weigel, and R. M. Wernberg. 2008. Evaluation of equations to predict dry matter intake of dairy heifers. J. Dairy Sci. 91:3699-3709.

Koch, R. M., L. A. Swiger, D. Chambers, and K. E. Gregory. 1963. Efficiency of feed use in beef cattle. J. Anim. Sci. 22:486-494.

Kruse, K. A., D. K. Combs, N. M. Esser, W. K. Coblentz, and P. C. Hoffman. 2010. Evaluation of potential carryover effects associated with limit feeding of gravid Holstein heifers. J. Dairy Sci. 93:5374-5384.
Macdonald, K. A., J. E. Pryce, R. J. Spelman, S. R. Davis, W. J. Wales, G. C. Waghorn, Y. J. Williams, L. C. Marett, and B. J. Hayes. 2014. Holstein-Friesian calves selected for divergence in residual feed intake during growth exhibited significant but reduced residual feed intake divergence in their first lactation. J. Dairy Sci. 97:1427-1435.

Mertens, D. R. 1973. Application of theoretical mathematical models to cell wall digestion and forage intake in ruminants. $\mathrm{PhD}$ Thesis. Department of Animal Science, Cornell University, Ithaca, NY.

NRC. 2001. Nutrient Requirements of Dairy Cattle. 7th rev. ed. Natl. Acad. Press, Washington, DC.

Pryce, J. E., J. Arias, P. J. Bowman, S. R. Davis, K. A. Macdonald, G. C. Waghorn, W. J. Wales, Y. J. Williams, R. J. Spelman, and B. J. Hayes. 2012. Accuracy of genomic predictions of residual feed intake and 250-day body weight in growing heifers using 625,000 single nucleotide polymorphism markers. J. Dairy Sci. 95:2108-2119.

Pryce, J. E., O. Gonzalez-Recio, G. Nieuwhof, W. J. Wales, M. P. Coffey, B. J. Hayes, and M. E. Goddard. 2015. Hot topic: Definition and implementation of a breeding value for feed efficiency in dairy cows. J. Dairy Sci. 98:7340-7350.

Quigley, J. D. III, R. E. James, and M. L. McGilliard. 1986. Dry matter intake in dairy heifers. 1. Factors affecting intake of heifers under intensive management. J. Dairy Sci. 69:2855-2862.

Radcliff, R. P., M. J. VandeHaar, A. L. Skidmore, L. T. Chapin, B. R. Radke, J. W. Lloyd, E. P. Stanisiewski, and H. A. Tucker. 1997. Effects of diet and bovine somatotropin on heifer growth and mammary development. J. Dairy Sci. 80:1996-2003.

Ribeiro, F. R. B., L. O. Tedeschi, J. R. Stouffer, and G. E. Carstens. 2008. Technical note: A novel technique to assess internal body fat of cattle by using real-time ultrasound. J. Anim. Sci. 86:763-767.

SAS Institute Inc. 2012. SAS User's Guide. Version 9.4. SAS Institute Inc., Cary, NC.

Schröder, U. J., and R. Staufenbiel. 2006. Invited review: Methods to determine body fat reserves in the dairy cow with special regard to ultrasonographic measurement of backfat thickness. J. Dairy Sci. 89:1-14.

Schulte, E. E., J. B. Peters, and P. R. Hodgson. 1987. Wisconsin procedures for soil testing, plant analysis, and feed and forage analysis. Dept. Soil Sci. Bull. No. 6. University of Wisconsin, Madison.

St-Pierre, N. R. 2007. Design and analysis of pen studies in the animal sciences. J. Dairy Sci. 90(E. Suppl.):E87-E89.

Tempelman, R. J., D. M. Spurlock, M. Coffey, R. F. Veerkamp, L. E. Armentano, K. A. Weigel, Y. de Haas, C. R. Staples, E. E. Connor, Y. Lu, and M. J. VandeHaar. 2015. Heterogeneity in genetic and non-genetic variation and energy sink relationships for residual feed intake across research stations and countries. J. Dairy Sci. 98:2013-2026.

Wildman, E. E., G. M. Jones, P. E. Wagner, R. L. Bowman, H. F. Trout Jr., and T. N. Lesch. 1982. A dairy cow body condition scoring system and its relationship to selected production characteristics. J. Dairy Sci. 65:495-501.

Williams, Y. J., J. E. Pryce, C. Grainger, W. J. Wales, N. Linden, M. Porker, and B. J. Hayes. 2011. Variation in residual feed intake in Holstein-Friesian dairy heifers in southern Australia. J. Dairy Sci. 94:4715-4725

Zanton, G. I., and A. J. Heinrichs. 2005. Meta-analysis to assess effect of prepubertal average daily gain of Holstein heifers on firstlactation performance. J. Dairy Sci. 88:3860-3867.

Zanton, G. I., and A. J. Heinrichs. 2007. The effects of controlled feeding of a high-forage or high-concentrate ration on heifer growth and first-lactation milk production. J. Dairy Sci. 90:3388-3396. 